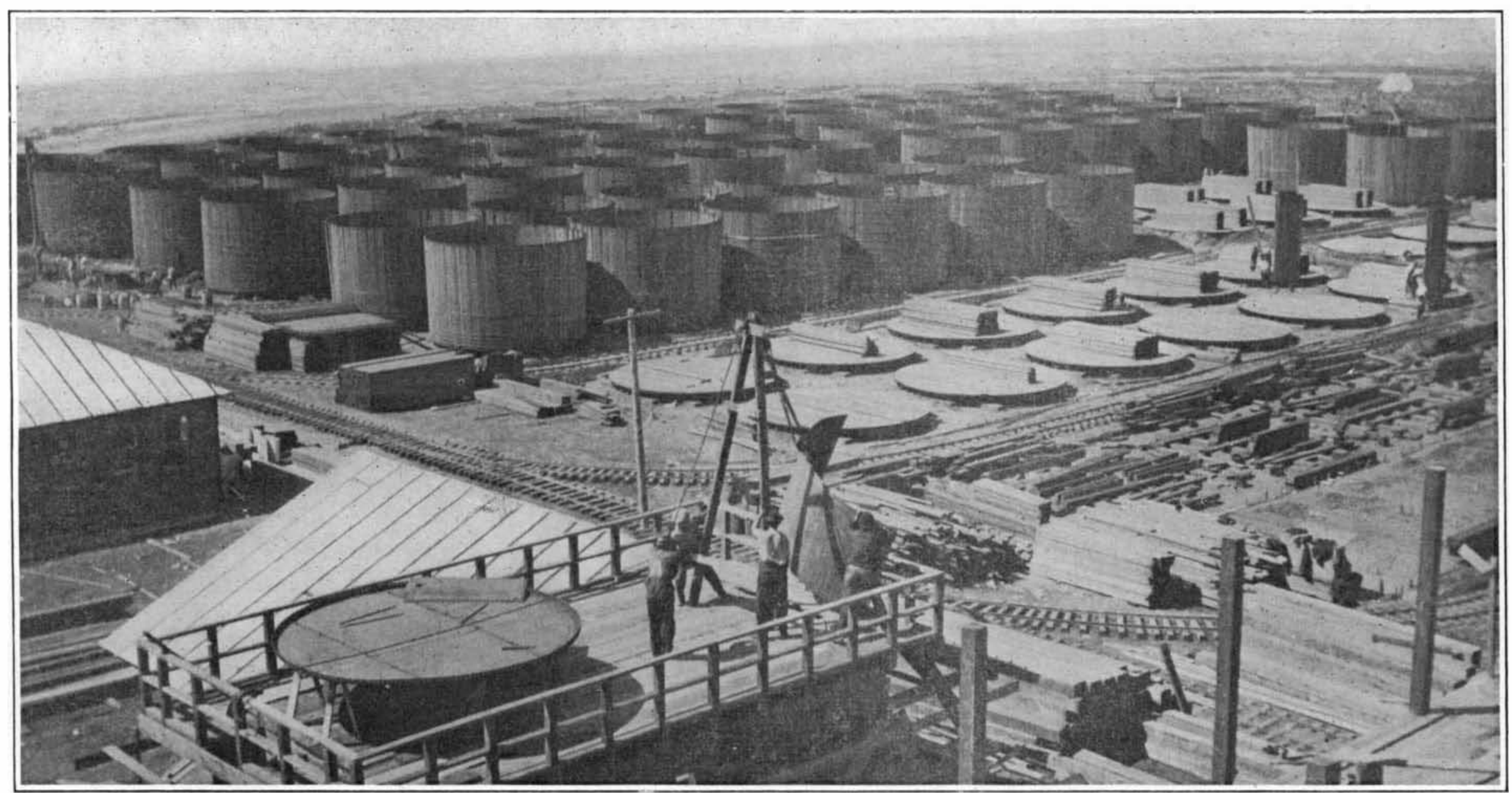

Photo by Cakfornis Redroood Association.

A GROUP OF 50,000GALLON REDWOOD TANKS AT MAN DEIGO, CALIFORNIA

\title{
The Cooperage Industry*
}

Wood Suitable for Barrels and Tests that Barrels Must Undergo By Hu Maxwell

THE cooperage industry includes the manufacture of barrels, kegs, staves, heading, hoops, and other articles made of staves.

The growth or decline of this industry from year to year cannot be conveniently shown, because the government compiles statiotics only every flve or ten years, and the cooperage associations have never brought figures together except in the most superficial way. It is known, however, that the cooperage industry is fairly stable and does not vary much from year to year. The greatest influence recently has been the prohibition movement which has threat-

- From Americon Forestry. ened to lessen the demand for barrels for spirituous
liquors. Such barrels constitute a rather small part
of the cooperage industry as a whole, and the di-
minution in the output of whiskey barrels will not
greatly lessen the cooperage production in the coun-
try. Similar changes have taken place before in the
cooperage businese, as in the substitution of bags for
barrels for cement, sugar, and flour; and pipelines
and tankcars in place of barrels in the transportation
of oil. In spite of such changes and fluctuations, the
cooperage business has moved steadily on. That lost
in one direction has been made up in another.
There are two kinds of cooperage, commonly dis- tinguished as "tight" and "slack." Tight vessels are intended for liquids; slack for dry anticles. Classes and grades come between the two extremes. The considered the o the vegetable slack barrel end of the business is the larger, judged by quantity of wood required in manufacturing the produot; but tight barrels demand a much higher grade of wood. The value of the slack stock used in the country is nearly fifty per cent. more than the value of the tight material. Nearly any wood is suitable for somekind of slack cooperage, but only a few are serviceable fortight.

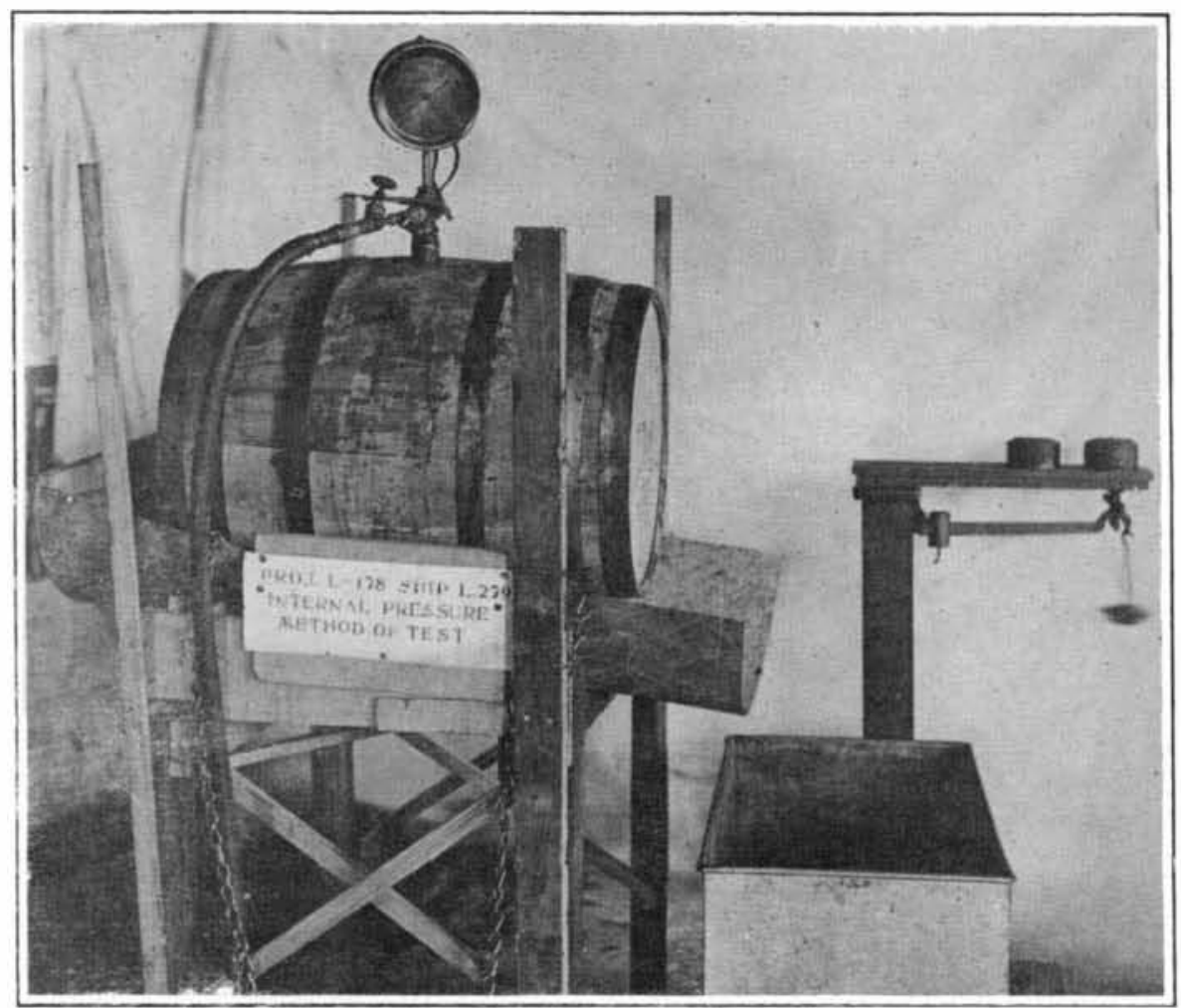

Testing the otreusth of a barrel by enbjecting it to intornal preacure

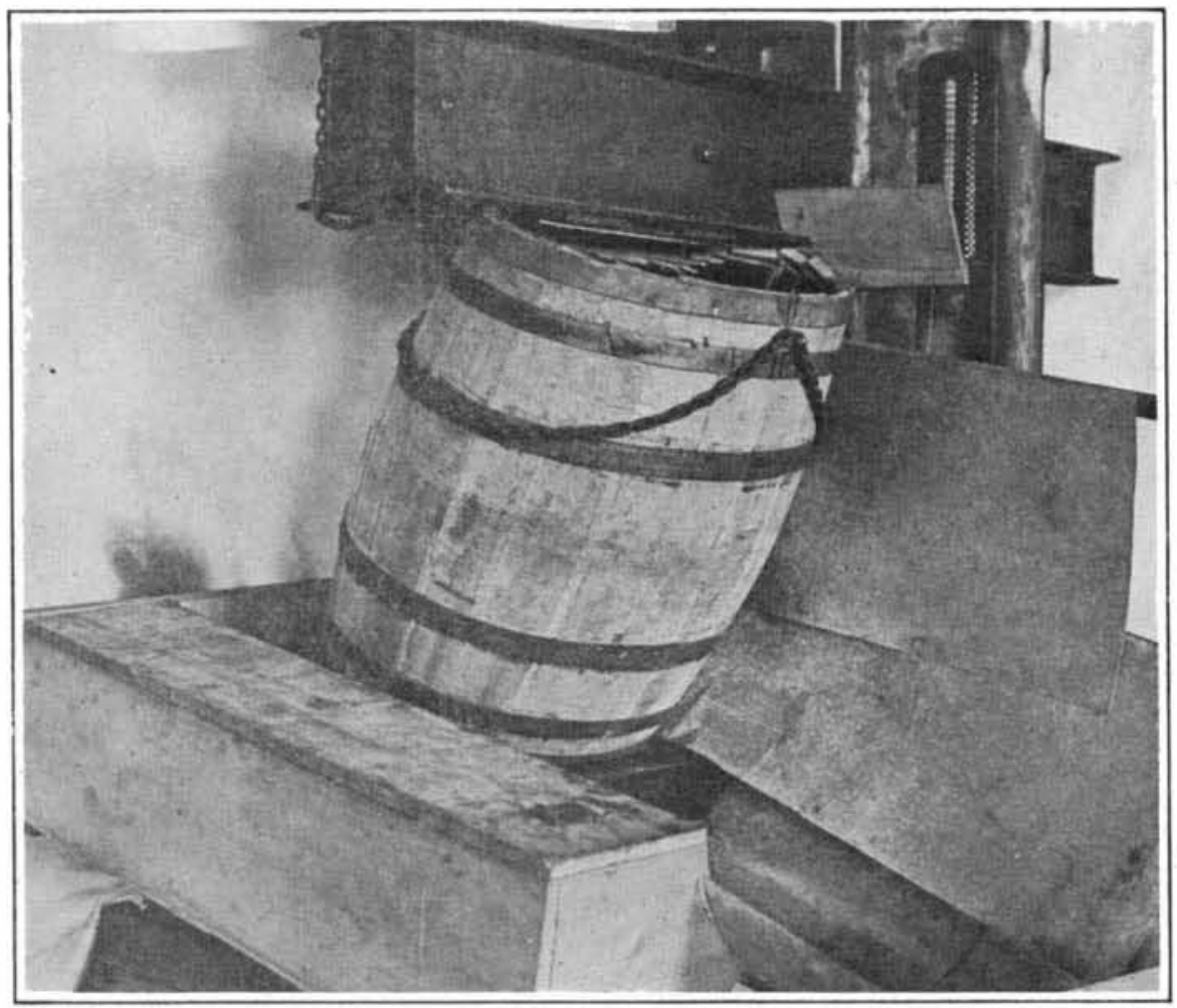

Determining how much bamping and tumbling a barrel will stand 


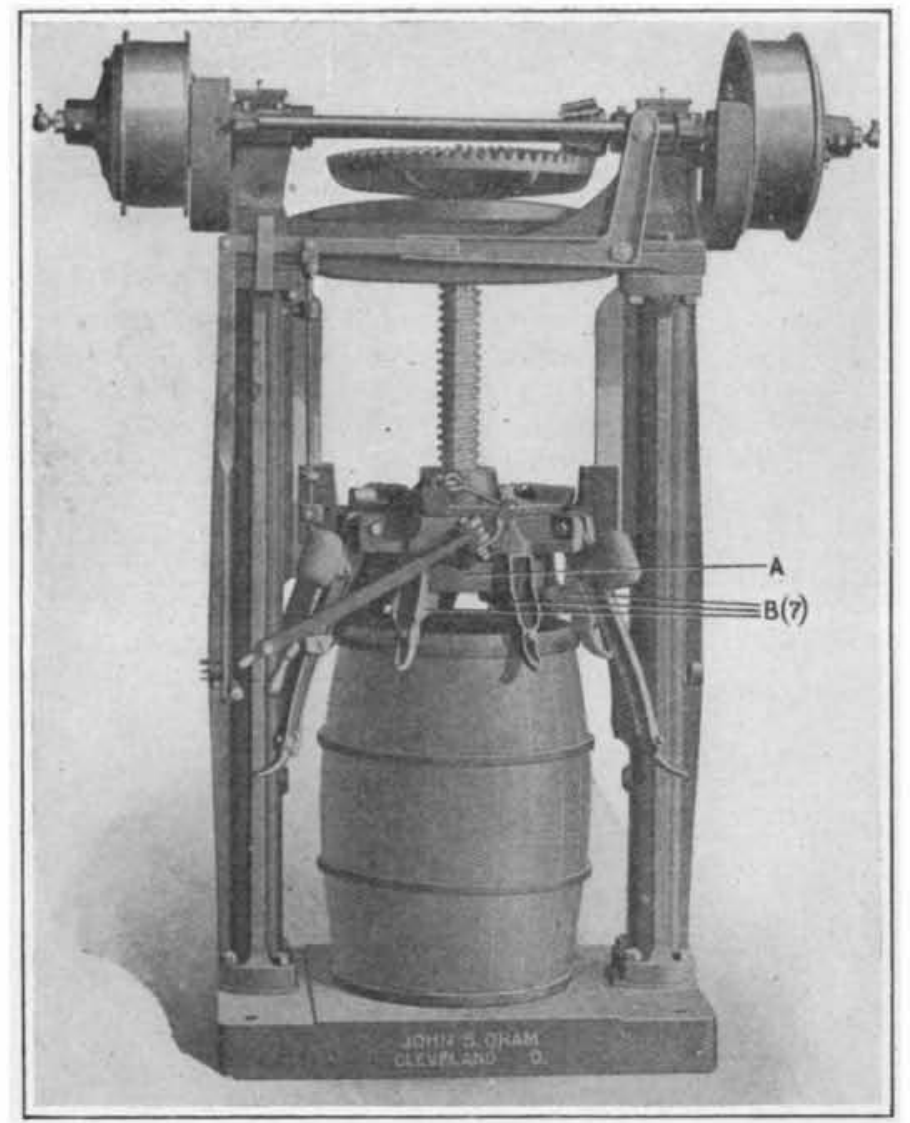

The barnel trusser at work

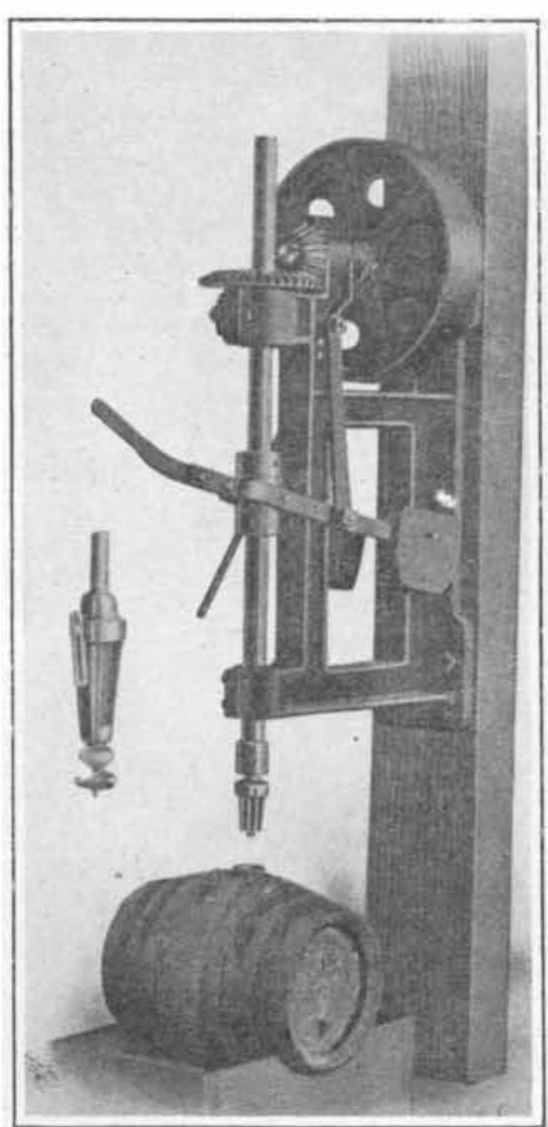

Boring and bushing the bung

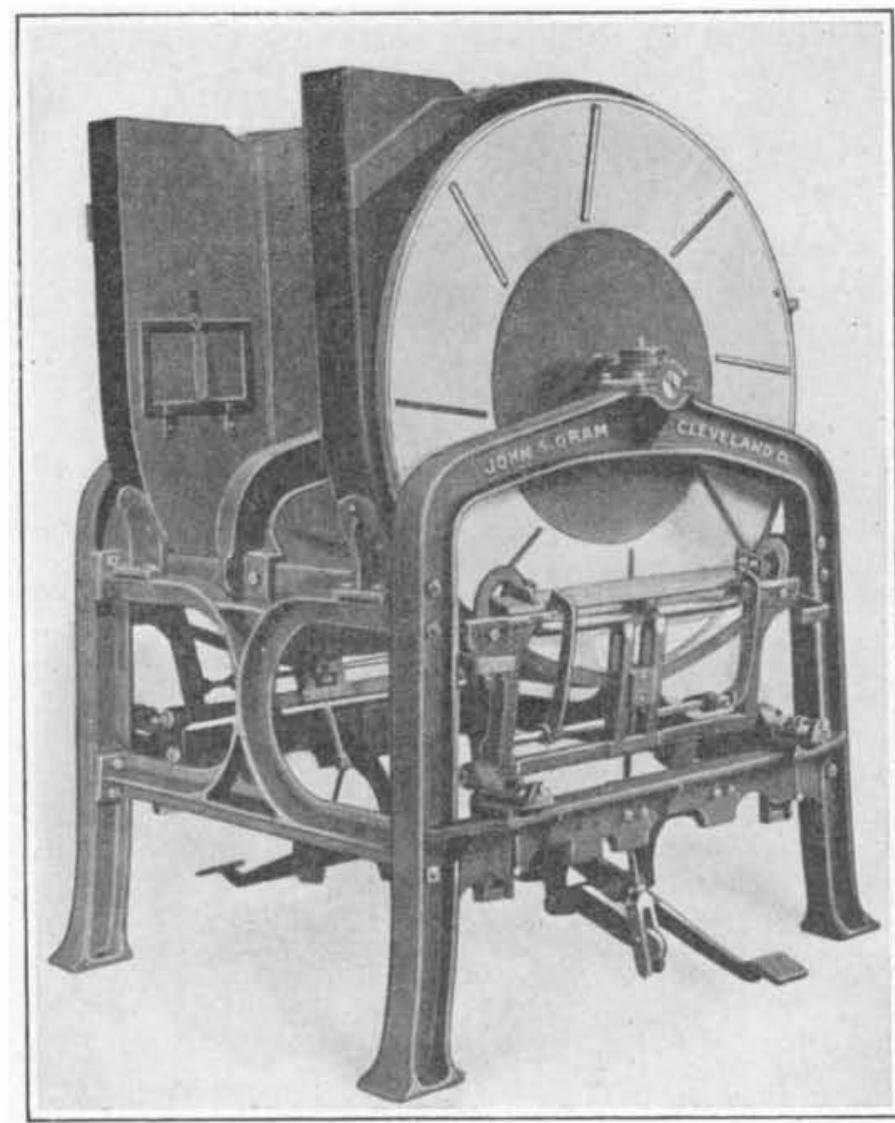

Heavy steel stave jointer
All cooperage whether tight or slack is made up of four to eight hoops make a barrel, but great varia. three parts, the staves, the heading, and the hoops. tion occurs in different kinds of barrels and kegs. No barrel is constructed without all three of these, The values in the United States in 1900 were, staves, though certain patterns of veneer drums combine the $\$ 11,477,399$; heading, $\$ 6,138,881$; hoops, $\$ 2,578,845$ staves and the hoops in the wooden sheet that forms The following list shows the woods from which the the body of the vessel. No well defined line of de- slack staves were made, and the number made from markation separates the barrel from the hamper or each:

stave basket, and sometimes it is not easy to say Red gum, 416,570,000; pine, 306,621,000; beech, which is which. The manufacturing of the three $268,237,000$; elm, 245,172,000; maple, 133,255,000 parts often constitutes three separate industries, a chestnut, 93,290,000; birch, 78,897,000; basswood,

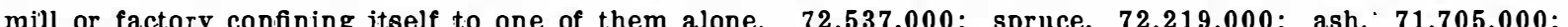
The three parts are often brought together by the oak, 66,675,000; cottonwood, 66,260,000; tamarack. user who assembles them as the barrels are needed; 28,832,000; cypress, 25,673,000; tupelo, 22,500,000; but not infrequently a single factory turns out fin- sycamore, 17,831,000; hemlock, 10,376,000; cedar, ished barrels which are then distributed to the users. 9,410,000; yellow poplar, 7,851,000; balsam, 6,037,The woods for the three parts are not always inter- 000; Douglas fir, 5,165,000; willow, 3,287,000; al changeable. Heading woods may not be satisfactory other, 1,128,000; total, 2,029,548,000.

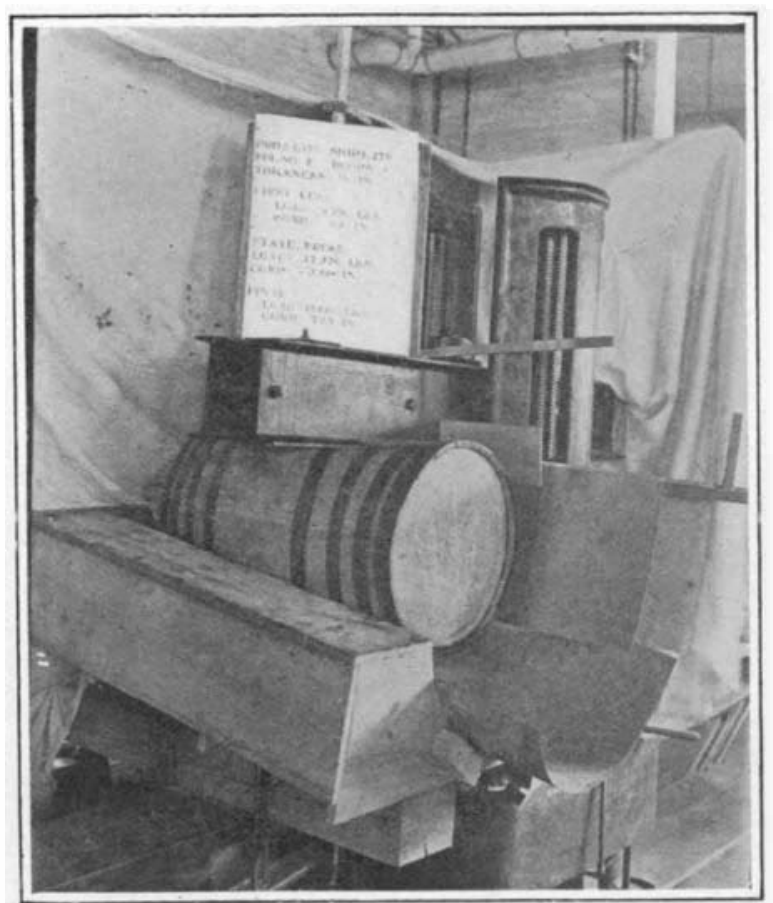

Gaging pressure on the barrel's side

In holds of ships barrels are sometimes piled ten feet high and the lower ones are liable to be crushed.

for staves; that for staves may be objectionable for heading; while hoop woods are not wanted for heading or staves. Steel is being substituted for wood in cooperage, there being steel barrels without a particle of wood; but the most common substitution is wire or strap metal for hoops.

In the year 1909 there were in the United States 1,506 establishments producing slack cooperage. They manufactured 2,029,548,000 staves, $140,234,000$ sets of heading, and 375,793,000 hoops. Usually sixteen slack staves, two sets of heading, and from

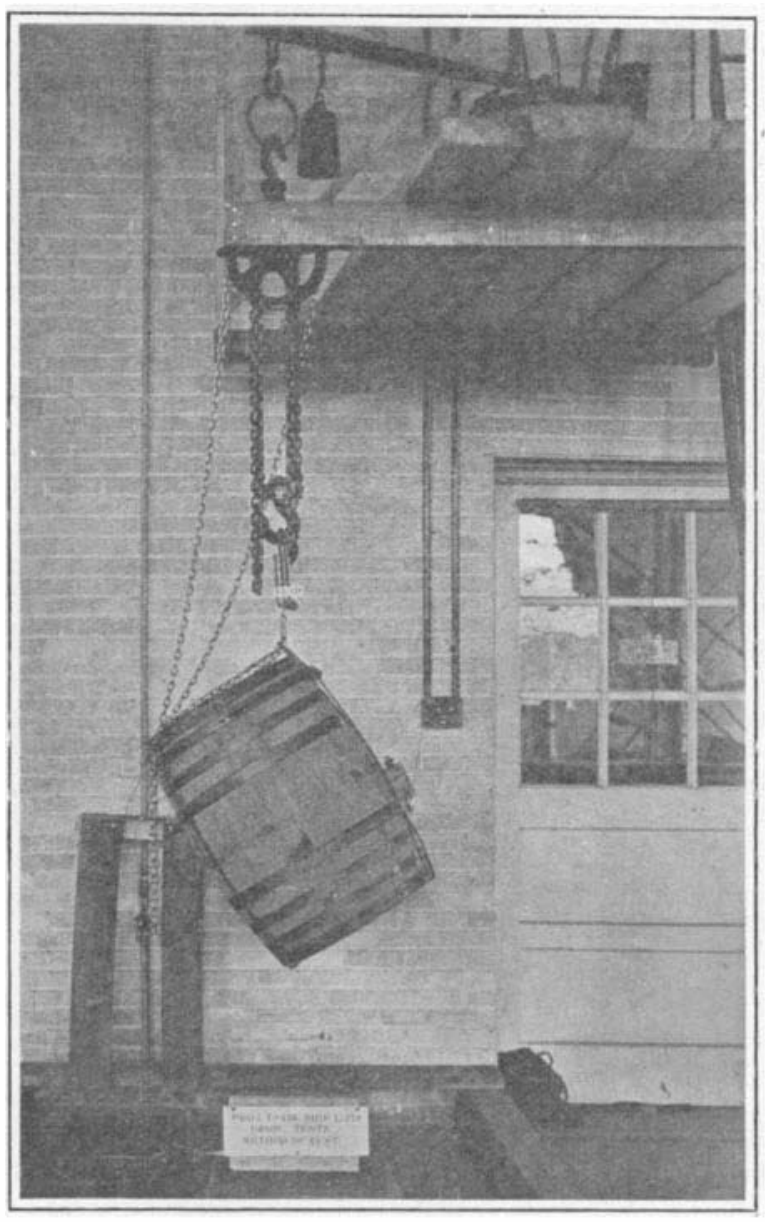

The chine test for barrels

The laad is not applied squarely on the head nor on the side but on the chine, subjecting the hoops and staves to strain.

Room exists for considerable choice of wood for staves in slack cooperage, but not so much for containers of liquids Flour barrels were once made principally of cottonwood staves, but elm has proved to be a good substitute. A white wood that presents a clean appearance is wanted, and it must be tough enough. and strong enough to carry the load. It must be free from odor or taste that might injure the contents. The sugar barrel demands material of the same kind.

Red gum leads all other woods because it is abundant and satisfaotory. The shippers of butter, lard meat, and other wood products select the most suitable woods for their barrels. Custom has much to do with it, bu do with it, but not a that a pine barrel might taint food with the taste of turpentine. The hardwoods are demanded in three times the number for slack barrels as are the softwoods; yet many commodities go to market in softwood barrels and kegs. Scrub pine is used for nail kegs and for containers of other small hardware. Timber which is fit for little else, and poles only a few inches in diameter, are sawed into staves.

All of the stave woods listed above are likewise used for heading, except cypress; but pine heading is consumed in twice the amount of any other and beech stands second, with red gum third. The heads of various sizes are cut with special machines. Slabs from sawmills, are cut in rather large quantities into

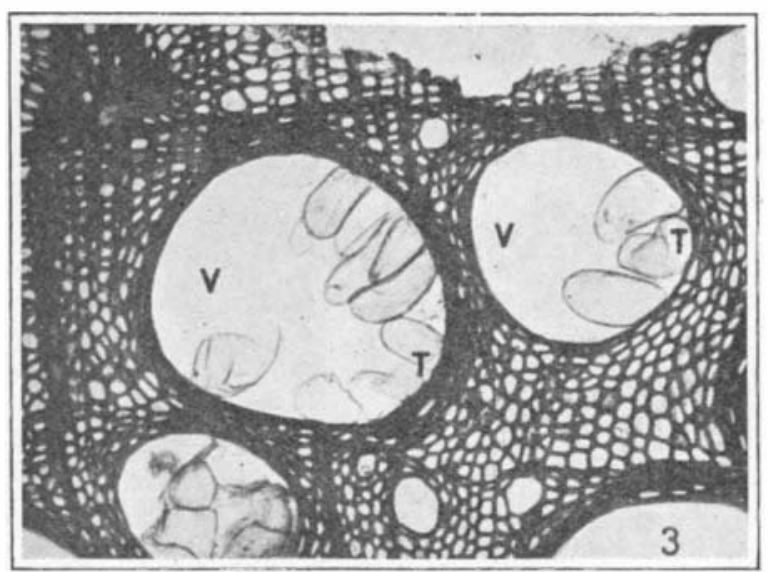

Why white oak does not leak

The pores are plugged by a growth called tylosis which is lere shown in process of formation

heading, and by combining a slack cooperage operation with lumber production, better utilization of the wood is secured. The coopers use the waste from the sawmill. Short and defective logs can be worked into staves and heading. Michigan leads all other states in slack cooperage production.

In the production of hoops, Ohio leads all other states, and is followed in the order named by Indiana, Michigan, Missouri, and Arkansas. Woods suitable for hoops are not so numerous as those for staves and heading. Toughness and strength are es- 
sential in hoop woods, for the hoop must bend without breaking. Following is a list of hoop woods and the annual output of hoops from each in the United States:

Elm, 339,477,000; red gum, 9,877,000; pine, 8 321,000 ; birch, 6,051,000; beech, 3,560,000; ash $2,020,000$; oak, $1,160,000$; maple, 731,000 ; spruce 106,000 ; basswood, 30,000 ; cedar, 5,000.

Though these figures were published under government authority, those purporting to give the production of pine hoops have been questioned by manufacturers who do not believe that so many pine hoop are made. The unfitness of pine for hoops throw suspicion on the figures.

Two styles of wooden hoops are in use, the coile and the straight. The coiled hoop is manufactured from logs, the wood being elm almost exclusively: and the straight hoop may be so made, or it may be shaved from little saplings called hoop poles, each large enough for one or two hoops. If two hoops are made from the pole, it is first split down the center and a hoop is shaved from each half. The making of hoops from hoop poles was one of the earliest wood-using industries of America, and the history of the business would read like a romance, though it deals with no very startling events. Som of the earliest hoops made in this country bound fish casks in New England, tar barrels in the Carolinas, and tobacco hogsheads in Virginia and Maryland. number of woods were available for this commodity. In New England the long, pliant whips of white or old fleld birch (Betula populifolia) were the best, and most of them still wore the bark on one side when they went on the barrel or keg. Further south hickory held its ground as a hoop pole wood against all rivals; and very early in Virginia's history a writer sounded the warning that so many choice young hickories were being made into hoops for tobacco hogsheads, that future hickory forests would suffer. Frequently thirty or forty hoops were used on one hogshead; not all at once, but it was the custom to cut off the hoops and expose the tobacco to view whenever a prospective buyer appeared, and afterwards replace the staves and put on new hoops.

The hoop pole business was once active in nearly all the eastern and middle western communities, and the name "Hooppole" is carried by more than one county to perpetuate the memory of an early flourishing business in this branch of cooperage. A number of woods, besides birch and hickory, are good for hoop poles.

Extensive use is made of barrels and kegs as shipping containers, and in some places they compete with boxes while in others they hold the field to themselves. The life of a barrel is put down at one year by the trade, but that is not enough. A majority of barrels are used many times. They begin as sugar or flour barrels, and are then sold to the farmer for shipping his produce to market. It may be said that shipping his produce to market. It may be said that
they are returned to him several times, carrying potathey are returned to him several times, carrying potalettuce on the next, each cargo being lighter in weight than the previous one, owing to the weakened condition of the barrel. Finally the barrel may serve out its life work as a trash receptacle, and in the end can be used for fuel. Thus it may be said that a barrel fills as useful a career as almost any other manufactured article, and its life is much longer than a season.

The demand for barrels is constantly growing, because modern machinery has made it possible to make them for the trade cheaper than almost any othe form of durable package. That it is the most con-

venient form of package has long been acknowledged

The heaviest demand comes from the cement business, and flour ranks next, closely followed by sugar and salt. As containers for fence, staples, bolts, nuts, nails, and packages for roasted coffee, spices, nuts, nails, and packages for roasted coffee, spices,
crockery, fruits, and vegetables, they follow in the crockery, fruits, and vegetables, they follow in the
order named. Glass manufacturers, baking powder companies, liquor distillers, and candy, tobacco, and cheese packers are big users of barrels. The demand for barrels for molasses, oil, lard, and pork, is also enormous, while dry paint, glue, snuff, aatmeal, screws, castings, and general hardware articles annually increase the demand on the cooperage supply.

Some woods are waterproof, others are not. Alcoholic liquors and some oils will pass through th pores of some woods where water will not go. The wood of which a whiskey barrel is made may absorb staves and wcaping. Some woods are so porous that barrels made of them will not hold water very long. Coopers learned by experience that certain kinds of Coopers learned by experience that certain kinds of
wood made better staves than others, when the bar- rels were intended for liquid. It was wholly a matter of experience at first, but later the microscope and to explain why some are proof against seepage and other are not. All wood is more or less porous. It is made up of hollow cells, connected one with
another by small openings, all microscopic in size; but some of the hardwoods have openings muc larger than cells. They are tubes running throug the wood, up and down the trunk of the tree, and are called pores or vessels. Some of them, as in oak and ash, are large enough to be seen by the unaided eye, by inspecting the end of a treshly cut stick. T'hese pores are responsible for the fact that some These pores are responsible for the fact that some
barrels will not hold liquid. It seeps into the pores and fiows along them until it passes entirely through the staves and escapes. That is why wood with large pen pores is not suitable for tight barrels.

White oak has always been considered the best for cooperage wood. Many years ago it was thought that no other could or should be used for certain liquid commodities, but others have lately come into use. Yet, white oak has large pores, and a casua observer noting that characteristic would conclud that it is not good for tight barrels, but experience shows it to be good. Though it has large pore which may be easily seen, they are not open. They are closed as a bottle is closed with a cork, and liquid cannot enter. The plugging substance, which is known a tylosis, is of a whitish color and is deposited in the pores by the wood itself, in the progress of the tree's growth and maturity. It occurs principally after the sapwood has changed into heartwood. Red oak' pores are not plugged. Therefore, red oak

uitable for the best kinds of tight cooperage.

The condition of the pores, whether they are able for tight than for slack cooperage. The following table gives the kinds and the number of tight staves made annual in this country from each of everal woods:

White oak, 217,019,000; red oak, 30,619,000 basswood, 30,589,000; gum, $23,566,000$; pine, 20 ,-
648,000 ; ash, 5,568,000; all other, $13,250,000$; total, $341,250,000$.

Only the best wood is used as barrels for alcoholic liquors; but some other woods will do for other kinds of liquors, such as brine for pork, vinegar for pickles, and for certain oils.

Tight barrels are of several sizes. The strongest, heaviest staves are for beer barrels and kegs. The staves are manufactured by several different processes and are named accordingly, as sawed, hewed, and bucked and split. The tight cooperage industry is well distributed over the country but is more important in some sections than in others, depending in the various parts of the country. The leading in the various parts of the country. The leadin
states in annual production of tight staves are her states

Arkansas, 87,582,000; Kentucky, 45,694,000; West Virginia, 40,402,000; Mississippi, 39,052,000; Tennessee, 35,744,000; Ohio, 26,534,000; Missouri, $22,420,000$

The waste of wood in the manufacture of tight staves in the past has been very great, but it is not now so great as formerly, because utilyzation is closer, and material which would have been thrown away formerly is now converted in to other products. Much of the finest oak of the country was cut for staves in past years. The makers of this commodity went ahead of lumbermen in new territory, and being first in the oak region, they naturally sesected the best oak trees, took the choicest portions of the trunks, and rejected the rest. They made no attempt to use wood which did not split well, and the stave maker's verdict: "It won't rive," was final and consigned the tree to the waste $h$ eap. It meant the abandonment of an oak trunk which might contain 3,000 or even 5,000 feet of lumber. That does not often occur now, for a sawmill is usually within reach and what cannot be split for staves can be sawed for lumber,
or the logs may be sent to a mill equipped to or the logs may

It was once a common situation in forests where stave makers were operating, for the ground to be covered with refuse billets and bolts which were left to rot because they were not just what the operator wanted. The workmen had no compunction when they left on the ground enough oak to make a thousand staves. Good trees were plentiful, and the stave makers turned their backs upon heaps of slightly defective bolts and went to work with their axes to fell other trees. Even when the operator had no fault to find with his timber, he usually left twice as much on the ground as waste as he took away as staver.
Families living near the stave operations in the forests often secure sufficient waste oak to provide household fuel for years; and most of it was of such high grade stuff that it would have passed inspection by any furniture factory, had it been sawed into 'lumber instead of being split and slaughtered in the process of stave making.

Staves were saleable at good prices at a time and in regions where no market for lumber existed, and for that reason the stave operator was in advance of the lumberman in $n e w$ country. Little capital was required in making staves when the farmer owned plenty of good oak timber, could buy a crosscut saw for eight dollars, an ax for a dollar, iron wedges for a dollar, a froe for the same, and could make his own maul, mallet, and wooden gluts; and the fork of a log served him for a riving horse. Thus equipped, he was ready for business. He had few labor bills to pay, for he could do all the work without going outside of his own family for assistance. Some stave making is still done along similar lines, but not much. Oak stumpage now has value, and it is pretty hard to carry on the smallest operation without the investment of some cash capital. Less dependence is placed on hand labor than formerly and more in machinery; and machines are expensive.

Bungs and faucets are listed as cooperage though they are sometimes considered as belonging to the subdivision of woodenware which is regarded as a separate industry. The bung closes the opening in the barrel; a spile or spiler is a small plug for closing a vent in a barrel or cask; while a faucet or spigot is a contrivance for drawing liquids from a barrel. The manufacture of these small wooden articles requires more than $21,000,000$ feet of lumber a year, ninety per cent of which is yellow poplar, which is the best bung wood known. It contains no hard and soft streaks, therefore it may be cut with a smooth surface, which insures' a close fit withou leakage. The wood is dense enough to prevent liquids from seeping through, but it imbibes sufficient moisture to swell the wood, insuring a still closer fit. Walnut and red gum have been used to a limited extent for bungs and a requite satisfactory. Bungs are cut by machinery from lumber an inch or more in thickness. A larger quantity is made in Cincinnati, Ohio, than in all the rest of the United States. The faucet is seldom sold along with the barrel but is a separate article. It is made in many pattern and of many woods, among them being white pine, pruce, maple, birch, beech, red gum, redwood, chestnut, cedar, walnut, and rosewood. A superstitio formerly was to be met with that the wood of which a spigot was made exercised an infiuence upon the liquid which flowed through it; and for that reason molasses should be drawn through a maple spigot only, beer through one of birch, and cider through one of applewood. The applewood spigot was strongly insisted upon for cider, and it has been currently believed that much applewood is still consumed in the manufacture of faucets for cider barrels. The superstition must have lost its power if it ever had any, for an examination of statistical reports of woodworking does not show the use of a single foot of applewood for faucets in the United States. Sailors along the Atlantic coast in early years insisted upon equipping their water casks with white cedar faucets because of the reputed esoteric purifying qualities of the wood. Fishermen from New England and Canada, who drank spruce beer while on the New Foundand Banks, saw to it that their beer was draw through no spigot but one made of spruce wood.

Many omall articles made of staves are commonly classed as woodenware rather than as cooperage, mong such being pails, buckets, keelers, measures, tubs, tool-dishes, and piggins. These have bottoms but no heads. The exact definition is not very important, for cooperage is a term broad enough to in clude all of them. The making of cedar pails wa once a very important occupation in and about Philadelphia, the materials being both the white and the red cedars of that region, and the makers were known as "the cedar coopers."

\section{The Highest Village on Earth}

A writer in a recent issue of L'Astronomie, calls attention to a tiny village in Kashmir, which holds the lofty distinction of being the highest on earth. This village, which bears the name Karzok, is located at latitude $32^{\circ} 58^{\prime} 0^{\prime \prime} .90$ North and longitude $78^{\circ}$ $18^{\prime} 13^{\prime \prime} .95$ East from Greenwich. Its altitude is 4556 meters or 14,946 feet. The village contains a few wretched stone houses and a small Buddhist monastery. 